\title{
Heavy metals contamination of a Mediterranean Coastal Ecosystem, Eastern Nile Delta, Egypt
}

\author{
Hamed A. El-Serehy ${ }^{1}{ }^{*}$, Hamdy Aboulela ${ }^{2}$, Fahad Al-Misned ${ }^{1}$, Mona Kaiser ${ }^{3}$, \\ Khaled Al-Rasheid ${ }^{1}$, Heba Ezz El-Din ${ }^{4}$ \\ ${ }^{1}$ King Saud University, College of Science, Department of Zoology, P.O. Box 2455, Riyadh 11451 Saudi Arabia. \\ ${ }^{2}$ Suez Canal University, Faculty of Science, Marine Science Department, Ismailia, Egypt. \\ ${ }^{3}$ Suez Canal University, Faculty of Science, Geology Department, Ismailia, Egypt. \\ ${ }^{4}$ Port Said University, Faculty of Science, Marine Science Department, Port Said, Egypt. \\ * Corresponding Author: Tel.:+966.1 4675758; Fax: +966.1 4678514; \\ E-mail: helserehy@ksu.edu.sa \\ Received 30 November 2011 \\ Accepted 25 May 2012
}

\section{Abstract}

The concentrations of $\mathrm{Fe}, \mathrm{Mn}, \mathrm{Zn}, \mathrm{Cu}, \mathrm{Pb}$ and $\mathrm{Cd}$ in bottom sediment and surface water in the Egyptian coastal waters along the Mediterranean Sea, and thence the soft tissues of the bivalve (Donax trunculus) were determined. The mean concentrations $\left(\mu \mathrm{g} \mathrm{g}^{-1}\right)$ of heavy metals in bottom sediment were as follows: Fe: 1748.2-2030, Mn: 191.4-254.3, Zn: 28-42.2, $\mathrm{Cu}: 4-9.4, \mathrm{~Pb}: 18.4-24.8, \mathrm{Cd}: 1.4-2.3$, and in surface water: Fe: 744-896, Mn: 162-198, Zn: 242.6-300, Cu: 12.6-19.3, Pb: 31.3-56, Cd: $0.8-3.1$, while in soft tissues of the bivalve $D$. trunculus, the mean concentrations $\left(\mu \mathrm{g} \mathrm{g}^{-1}\right.$ dry weight) were as follows: Fe: 47.2-66.4, $\mathrm{Mn}: 4.8-8.4, \mathrm{Zn}: 22-36.4, \mathrm{Cu}: 3.2-4.8, \mathrm{~Pb}: 5.6-9.2, \mathrm{Cd}: 1.6-2.4$. The present study has revealed that the concentrations of $\mathrm{Cd}$ and $\mathrm{Pb}$ in the soft tissues of the edible bivalve $D$. trunculus were above the maximum acceptable concentrations for human consumption proposed by FAO/WHO, EU. Moreover, estimation of concentration factor $\left(\mathrm{C}_{f}\right)$ for the studied metals in the soft tissues of the edible bivalve D. trunculus recorded high accumulation rates of $\mathrm{Cd}$ and $\mathrm{Cu}$. The present study confirmed that, the examined bivalve species was associated with enhanced metal content in its soft tissues and was not safe within the limits for human consumption. Water and bottom sediments showed apparent seasonal variations of metals accumulation with maximum concentrations during summer and winter, respectively. Mean metal concentrations were found to be higher in some of the selected five sites than others, but, these differences in heavy metal concentrations were not statistically significant $(\mathrm{P}>0.05)$, suggesting that common and main anthropogenic sources contributing to the heavy metal pollution at this Egyptian coastal area on the Mediterranean sea. The results obtained in this study were compared with those reported in earlier studies and concluded that, the area of the present study was in general not considered a metal polluted area according to the OME and EPA classification criteria. However, concentrations of $\mathrm{Cd}$ and especially, $\mathrm{Pb}$ did give some cause for concern, and warrants a continued monitoring programme for inorganic and chemical organic compounds in sediments, water, and biota along the Egyptian Mediterranean coasts.

Keywords: Heavy metals, sediment, water, bivalve, Port Said, Mediterranean Sea

\section{Introduction}

Heavy metals are considered among the most serious contaminants of aquatic ecosystems, due to their high potential to enter and accumulate in food chain (Tam and Wong, 2000; Erdoğrul and Erbilir, 2007). Under certain environmental conditions in aquatic systems, heavy metals may accumulate to reach a toxic concentration and cause ecological damage (Jefferies and Firestone, 1984; Freedman, 1989). The main sources of heavy metal pollution are (1) the run-off from agricultural and urban areas, (2) discharges from mining, factories and municipal sewer systems, (3) leaching from dumps and former industrial sites, and (4) atmospheric deposition (Singh and Steinnes, 1994; Kumar Singh et al., 2007).

Coastal areas are characterized by high organic matter and nutrients from the continent, having fragile coastal ecosystem dependent on terrestrial conditions (Yáñez-Aracibia and Sánchez-Gil, 1988). Industrialization of coastal areas is very common in countries characterized by exploitation and importation economics, causing serious damage to coastal ecosystems, e.g. contamination of metals (Cardoso et al., 2001). Moreover, anthropogenic activities are known to have a wide range of potential effects of these coastal ecosystems, particularly from point and non-point sources of pollution. The release of pollutants into coastal environment is a major human concern worldwide. These contaminants are known to readily accumulate in bottom sediments which serve as a repository of pollutants. Sediment contaminants could be released to the overlying water, resulting in potential adverse health effects to aquatic organisms (Daskalakis and O'Connor, 1995; Long et al., 1995; Argese et al., 1997; Ross and 
Delorenzo, 1997; Freret-Meurer et al., 2010). Among the adverse health effects associated with these contaminants are toxicity to the kidney, nervous and reproductive systems, as well as endocrine disruption and mutations (Collier et al., 1998; Nirmala et al., 1999; Ketata et al., 2007; Liu et al., 2008; Brar et al., 2009). In addition, trace metals are known to bioaccumulate in edible aquatic organisms (e.g., mollusks), thus, representing a health risk to top predators, including humans (Fox et al., 1991; Renzoni et al., 1998; Huang et al., 2006; Díez et al., 2009).

The Egyptian coastline extends $3000 \mathrm{~km}$ along the Mediterranean Sea and Red Sea beaches in addition to the Gulf of Suez and Gulf of Aqaba. Unfortunately, most of the Egyptian coastal zones along the Mediterranean Sea are subjected to intense discharges of pollutants from numerous anthropogenic activities (Dowidar, 1988). A high profile example is the region of El-Gamil coast at the northwestern part of Port Said City (Kaiser et al., 2010). Contamination by trace metals has not been extensively studied in the Egyptian coastal zones along the Mediterranean Sea which are subjected to intense discharges of pollutants (Hamed, 1996; ElSikaily et al., 2004; El-Moselhy et al., 2005). Therefore, it is important that sediment and water contamination by these pollutants be assessed for better management and protection of these valuable costal ecosystems at El-Gamil beach along the western coast of Port Said on the Mediterranean Sea. Especially, this region represents a pronounced area for fishing, industrial development, urban extensions and more tourism activities along eastern Mediterranean Sea. This study aims to provide basic information for detecting the current status of heavy metal pollution in El-Gamil zone of the Egyptian coasts on southeastern Mediterranean Sea, and to determine if humans that consume the bivalve Donax trunculus from this region might be at risk for heavy metal-related health issues.

\section{Materials and Methods}

\section{Area of Study}

The study area constitutes a small part of the low lands lying west of Port Said City known as El-Gamil zone, which extends further west-wards parallel to the Deltaic Coast of the Mediterranean Sea. It is bordered by the Suez Canal to the east and by Lake Manzala to the south. It is situated about 13 kilometers west of Port-Said City and extends between latitude $31^{\circ} 10^{\prime}$ $31^{\circ} 20^{\prime} \mathrm{N}$ and longitude $32^{\circ} 00^{\prime}-32^{\circ} 20^{\prime} \mathrm{E}$ with about a $24 \mathrm{~km}^{2}$ coverage area. Five sites along El-Gamil beach, including El-Debba (site 5), El-Manasra (site 4), El-Fardous (site 3), El-Gamil inlet (site 2) and the El-Gamil airport (site 1) were chosen for this study (Figure 1). General features of anthropogenic activities at the study area with an emphasis on descriptive features of the sampling sites are listed in Table 1. Levels of six heavy metals (Fe, Mn, Cd, Zn, $\mathrm{Cu}$ and $\mathrm{Pb}$ ) were measured in bottom sediment, surface water and the muscle tissues of the bivalve samples collected from each site during December 2005 and August 2006.

\section{Analytical Procedure in Bottom Sediment, Surface Water and Bivalve}

A total of 30 sediment samples were collected from the five selected sites along El-Gamil coast during December 2005 and August 2006. The sediment samples were collected by pushing a plastic

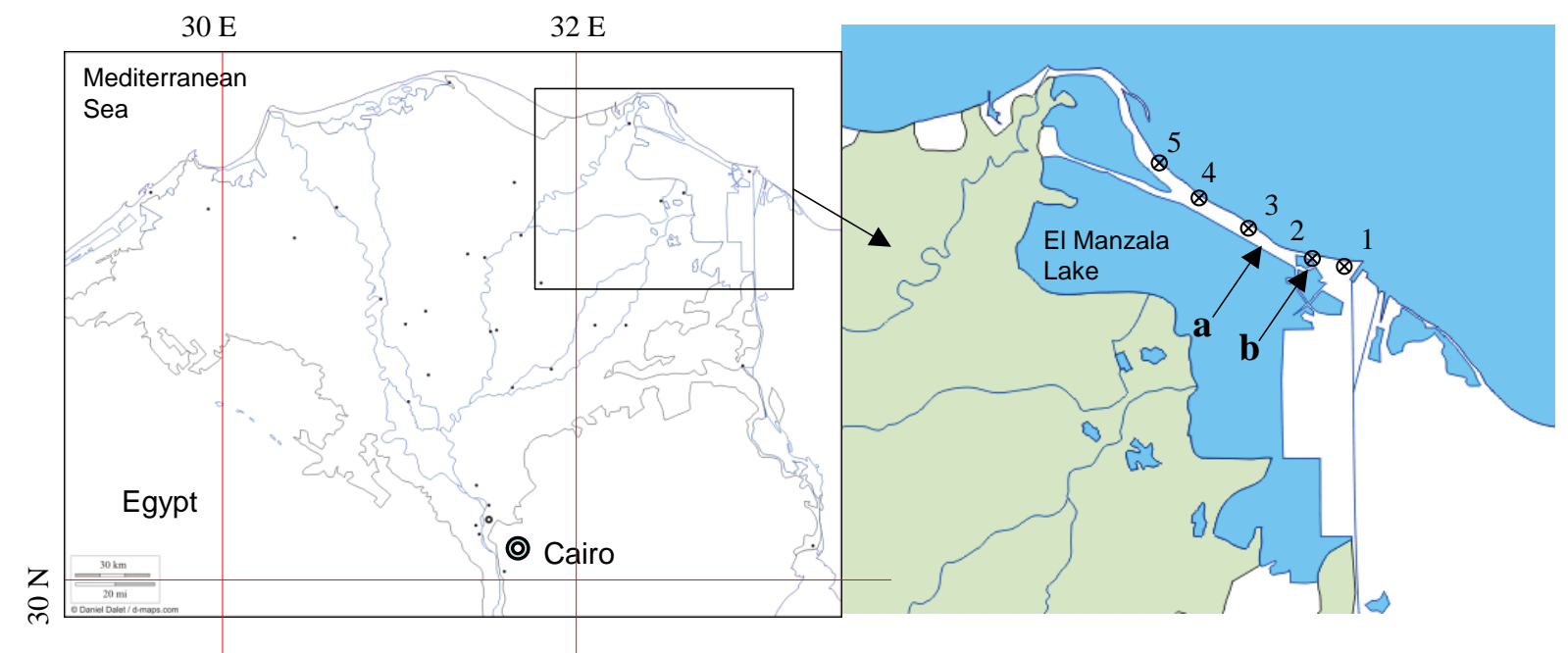

Figure1. Satellite image shows the location of the study area and the sampling sites on the Mediterranean Sea.

(1) El-Gamil airport, (2) El-Gamil inlet, (3) El-Fardous, (4) El-Manasra, (5) El-Debba

a $\rightarrow$ Boughaz El Gamil Unreated domestic sewage

$\mathrm{b} \rightarrow$ El Gamil Unreated domestic sewage 
Table 1. Locations and descriptive features of anthropogenic activities of sampling sites

\begin{tabular}{|c|c|c|}
\hline Sampling Sites & Coordinates of sampling sites & General features of anthropogenic activities \\
\hline El-Gamil Airport (Site 1) & $31^{\circ} 16^{\prime} 56^{\prime \prime} \mathrm{N}-32^{\circ} 14^{\prime} 36^{\prime \prime} \mathrm{E}$ & - El-Gamil Airport. \\
\hline El-Gamil Inlet (Site 2) & $31^{\circ} 17^{\prime} 25^{\prime \prime} \mathrm{N}-32^{\circ} 12^{\prime} 35^{\prime \prime} \mathrm{E}$ & $\begin{array}{l}\text { - Boughaz El-Gamil " } \\
\text { - El-Gamil and El-Abtal tourist villages } \\
\text { - Standing apart breakwaters }\end{array}$ \\
\hline El-Fardous (Site 3) & $31^{\circ} 18^{\prime} 12^{\prime \prime} \mathrm{N}-32^{\circ} 10^{\prime} 49^{\prime \prime} \mathrm{E}$ & $\begin{array}{l}\text { - Ashtoum El-Gamil } \\
\text { - El-Maghraby and El-Fardous tourist villages. } \\
\text { - Company of Natural gas Petroget }\end{array}$ \\
\hline El-Manasra (Site 4) & $31^{\circ} 19^{\prime} 45^{\prime \prime} \mathrm{N}-32^{\circ} 08^{\prime} 14^{\prime \prime} \mathrm{E}$ & $\begin{array}{l}\text { - Company of Petrobel Balaeim Natural Gas. } \\
\text { - International Factory of Pipelines Industry. } \\
\text { - Electric power generating station. } \\
\text { - Urban extension. } \\
\text { - Anti-fouling paints. }\end{array}$ \\
\hline El-Debba (Site 5) & $31^{\circ} 21^{\prime} 28^{\prime \prime} \mathrm{N}-32^{\circ} 0.4^{\prime} 50^{\prime \prime} \mathrm{E}$ & - Developing urban and traffic highway \\
\hline
\end{tabular}

core $(12 \mathrm{~cm}$ in diameter) into the bottom sediment to a depth of approximately $5 \mathrm{~cm}$. The samples were then put in plastic bags and transferred to the laboratory. Sediments were dried at $100^{\circ} \mathrm{C}$ for $24 \mathrm{hrs}$ and kept in plastic bags until analysis. A representative $50 \mathrm{~g}$ of sediment sample were repeatedly treated with hydrogen peroxide $(30 \%)$ in order to remove organic matter and the loss in weight was determined. Samples free of organic matter were also treated by using diluted $\mathrm{HCl}$ to remove calcium carbonates and the loss in weight was again determined, according to the method described by Folk, (1974). The grain size analysis of the examined samples was done according to Friedman and Johnson (1982). Dry sand was fractioned by dry sieving using sieves with openings of $2,1,0.5,0.25,0.125,0.063$ and $0.032 \mathrm{~mm}$ and an electric shaker. The weight percentages of the different size classes were calculated in three replicates per site sampled.

To detect heavy metal contamination in the sediment samples, an exact weight of dry sample $(0.5$ g) of each sediment sample was completely digested for about $2 \mathrm{hrs}$ in Teflon vessels using $5 \mathrm{ml}$ of analar grade nitric acid (triplicate digestions were made for each sample). The final solution was diluted to $25 \mathrm{ml}$ with distilled de-ionized water (Oregioni and Astone, 1984).

In tandem with the collection of the 30 sediment samples a further 30 surface water samples were collected at a depth of $0.5 \mathrm{~m}$ from the same five selected sites. Water samples were collected in one liter white polyethylene bottles, and filtered through a $0.45 \mu \mathrm{m}$ membrane. The filtered samples were placed in an ice-box, and transferred to the laboratory for storage at $4{ }^{\circ} \mathrm{C}$ until analysis. The concentration of the following heavy metals: $\mathrm{Fe}, \mathrm{Mn}, \mathrm{Zn}, \mathrm{Cu}, \mathrm{Pb}$ and $\mathrm{Cd}$ were determined by digesting $100 \mathrm{ml}$ of each water sample at $100^{\circ} \mathrm{C}$ in $5 \mathrm{ml}$ analar grade nitric acid $\left(\mathrm{HNO}_{3}\right)$ for 5 hours. The digested samples were allowed to stand over-night at room temperature before the residual being analyzed for heavy metals according to Standard Method 3110 (APHA, 1992).

Specimens of the most commercial bivalve $D$. trunculus were collected from the five sampling sites at the same time as the sediment and water samples by obtaining individuals with standard lengths between 1 and $3 \mathrm{~cm}$. Length and body weights were recorded for each specimen. Live samples were left in clean water for 30 minutes to purge their guts. Thereafter, the soft tissue only was kept in plastic bags and frozen until analysis. Before analysis, the soft tissue was dried at $70^{\circ} \mathrm{C}$ for $12 \mathrm{hrs}$ before analysis. An exact dry weight of sample $(0.5 \mathrm{~g})$ was digested in Teflon vessels with $5 \mathrm{ml}$ analar grade nitric acid $\left(\mathrm{HNO}_{3}\right)$, tightly covered and allowed to predigest overnight at room temperature. The digestion and preparation of bivalve samples for trace metal analysis was carried out according to (UNEP/FAO/IAEA/IOC, 1984).

The total concentrations of $\mathrm{Fe}, \mathrm{Mn}, \mathrm{Zn}, \mathrm{Cu}, \mathrm{Pb}$ and $\mathrm{Cd}$ metals in bottom sediment, surface water and the muscle tissue of the bivalve (D. trunculus) samples were analyzed using an atomic absorption spectrophotometer (AAS) (Perkin Elmer, Waltham, MA, USA, model 1200 A), at the El-Fostat Center, Cairo, Egypt, according to the Standard Method 3110 (APHA, 1992). The detection limits of the AAS used were $0.002 \mu \mathrm{g} / \mathrm{L}$ for $\mathrm{Fe} ; 0.001 \mu \mathrm{g} / \mathrm{L}$ for $\mathrm{Zn}$ and 0.0005 for $\mathrm{Mn}, \mathrm{Cu}, \mathrm{Pb}$ and $\mathrm{Cd}$, respectively. All analyses were carried out in triplicate. For each run, three "blanks" were analyzed using the same procedure in order to check the purity of reagents and any possible contamination.

\section{Statistical Analysis}

One-way analysis of variance test (Underwood, 1981) was followed. The significance levels of $5 \%$ (Steel and Torrie, 1988) were conducted on each metal to test for significant differences between sites. Organic matter-metal, $\mathrm{CaCO}_{3}$-metal, Sand-metal, siltmetal and inter-elemental relationships were performed through Pearson's correlation coefficient matrix. All statistical analyses were conducted using the Office Excel 2003 software package.

In addition to determine the level of metals in 
the edible bivalve $D$. trunculus soft tissues, the concentration factor values $\left(\mathrm{C}_{f}\right)$ for the six studied metals were calculated in the soft tissues of the bivalve according to the following formula:

$$
\mathrm{C}_{f}=\mathrm{C}_{x} / \mathrm{C}_{w}
$$

where: $\mathrm{C}_{x}$ and $\mathrm{C}_{w}$ are the mean concentrations of metals in the organism, and in the surrounding water, respectively.

\section{Results and Discussion}

The sediment at the five selected sites showed a high percentage of very fine and fine sand coupled with a low percentage of coarse fractions (Table 2). The maximum percentage of organic matter content was recorded at El-Gamil inlet and El-Fardous with values of $4.13 \pm 1.3 \%$ and $4.23 \pm 1.77 \%$, respectively. The high percentage of organic matter at these two sites can be attributed to the discharge of sewage wastes into the Mediterranean Sea through El-Gamil outlet and Ashtoum El-Gamil outlet along ElManzala Lake. Furthermore, untreated domestic sewage was discharged into the sea from four touristic villages in this coastal area vise: El-Gamil, El-Abtal,
El-Maghraby and El- Fardous. The calcium carbonate content was very high at El-Gamil airport (site 1) with a value of $27.53 \pm 5.10 \%$, while it was very low $(3.03 \pm 1.18 \%)$ at El-Debba (site 5). The high values of calcium carbonate content at site (1) can be attributed to the accumulation of large amounts of shell fragments blanketing the bottom sediment at ElGamil airport.

In the sediment samples, the concentration of heavy metals was higher during winter (Table 3). Even though there was variability among sites, the overall concentration range for a particular metal was relatively narrow, with no values that appeared to be unusual. Generally, in the sediment samples the heavy metals distribution followed the decreasing order of $\mathrm{Fe}>\mathrm{Mn}>\mathrm{Zn}>\mathrm{Pb}>\mathrm{Cu}>\mathrm{Cd}$. El-Manasra site demonstrated the highest level of heavy metal contamination recorded during the present study. This can be explained by the increasing industrial activities at this site, with natural gas companies, pipeline industries and an electric power generating station all operating in this area.

Classification of pollution level in relation to each element was determined according to the rules for sediment pollution adopted by the Ontario Ministry of the Environment (OME) and the United

Table 2. Results of bottom sediment analysis for the sediment samples collected from El-Gamil Beach during the present study

\begin{tabular}{lllllll}
\hline Site & $\mathrm{O} . \mathrm{M} \pm \mathrm{S} . \mathrm{D} \%$ & $\begin{array}{l}\mathrm{CaCO}_{3} \pm \mathrm{S} . \mathrm{D} \\
\%\end{array}$ & C.T $\pm \mathrm{S} . \mathrm{D} \pm \%$ & F.T $\pm \mathrm{S} . \mathrm{D} \pm \%$ & $\mathrm{Phi} \pm \mathrm{S} . \mathrm{D}(\Phi)$ & $\begin{array}{l}\text { Wentworth } \\
\mathrm{MZ}\end{array}$ \\
\hline El-Gamil Airport $\pm($ Site 1) & $1.91 \pm 0.06$ & $27.53 \pm 5.10$ & $0.55 \pm 0.82$ & $98.72 \pm 0.67$ & $2.66 \pm 0.15$ & Fine Sand \\
El-Gamil Inlet (Site 2) & $4.13 \pm 1.3$ & $6.53 \pm 1.42$ & $0.4 \pm 0.45$ & $97.04 \pm 0.76$ & $3.0 \pm 0.2$ & Very fine sand \\
El-Fardous (Site 3) & $4.23 \pm 1.77$ & $4.6 \pm 1.96$ & $0.13 \pm 0.03$ & $98.77 \pm 0.62$ & $2.73 \pm 0.15$ & Fine Sand \\
El-Manasra (Site 4) & $3.86 \pm 0.64$ & $4.46 \pm 2.66$ & $0.346 \pm 0.42$ & $98.02 \pm 0.414$ & $2.66 \pm 0.15$ & Fine Sand \\
El-Debba (Site 5) & $2.5 \pm 0.56$ & $3.03 \pm 1.18$ & $0.843 \pm 0.69$ & $98.96 \pm 0.13$ & $2.71 \pm 5.44$ & Fine Sand \\
\hline
\end{tabular}

O.M: Organic Matter; $\mathrm{CaCO}_{3: \pm}$ Calcium Carbonate; C.T: \pm Coarse Truncation; F.T: \pm Fine Truncation; S. D: \pm Standard Deviation; Phi $(\Phi)$ : Size of Sand Grains.

Table 3. Mean concentration of total heavy metals \pm standard deviation in sediment samples collected from El-Gamil Coast during winter 2005 and summer $2006($ Mean \pm S. D)

\begin{tabular}{llrrrrr}
\hline Metal & Season & \multicolumn{5}{c}{ Sites } \\
\cline { 3 - 6 } & & \multicolumn{1}{c}{$\begin{array}{c}\text { El-Gamil Airport Site } \\
\text { El }\end{array}$} & $\begin{array}{r}\text { El-Gamil Inlet Site } \\
\text { El-Fardous Site }\end{array}$ & $\begin{array}{r}\text { El-Manasra Site } \\
\text { El-Debba Site } \\
(5)\end{array}$ \\
\hline $\mathrm{Fe}(\mu \mathrm{g} / \mathrm{g})$ & Winter & $1936.5 \pm 45.2$ & $1927.1 \pm 48.5$ & $1865.7 \pm 38.3$ & $1968.7 \pm 76.2$ & $2030 \pm 4.8$ \\
& Summer & $1830.4 \pm 68.8$ & $1837.6 \pm 47.1$ & $1748.2 \pm 44.1$ & $1888.6 \pm 145.7$ & $1918.7 \pm 24.7$ \\
$\mathrm{Mn}(\mu \mathrm{g} / \mathrm{g})$ & Winter & $200.8 \pm 16.5$ & $204.2 \pm 13.5$ & $213.5 \pm 8.3$ & $254.3 \pm 16.6$ & $229.4 \pm 32.7$ \\
& Summer & $197.2 \pm 12.8$ & $202.9 \pm 4$ & $191.4 \pm 4$ & $217.8 \pm 33$ & $208.3 \pm 8.1$ \\
$\mathrm{Cd}(\mu \mathrm{g} / \mathrm{g})$ & Winter & $2.1 \pm 0.4$ & $2 \pm 0.11$ & $1.8 \pm 0.3$ & $2.3 \pm 0.46$ & $2.2 \pm 0.05$ \\
& Summer & $1.9 \pm 0.41$ & $1.4 \pm 0.23$ & $1.8 \pm 0.3$ & $2 \pm 0.57$ & $1.9 \pm 0.2$ \\
$\mathrm{Zn}(\mu \mathrm{g} / \mathrm{g})$ & Winter & $33.9 \pm 3.4$ & $34.6 \pm 2.1$ & $33.1 \pm 1.3$ & $42.2 \pm 1.5$ & $36.9 \pm 5.5$ \\
& Summer & $30.4 \pm 2.4$ & $32.4 \pm 2.9$ & $28 \pm 3.7$ & $36.6 \pm 6$ & $32.5 \pm 0.94$ \\
$\mathrm{Cu}(\mu \mathrm{g} / \mathrm{g})$ & Winter & $4 \pm 3.1$ & $4.2 \pm 3.4$ & $6.7 \pm 2.3$ & $9.4 \pm 0.4$ & $8.7 \pm 1$ \\
& Summer & $6.6 \pm 1.6$ & $5.7 \pm 1.1$ & $6.6 \pm 1.6$ & $9.4 \pm 1$ & $7 \pm 1.3$ \\
$\mathrm{~Pb}(\mu \mathrm{g} / \mathrm{g})$ & Winter & $23.8 \pm 4.1$ & $18.4 \pm 2.5$ & $20.2 \pm 4.1$ & $22.8 \pm 3.4$ & $24.8 \pm 1.3$ \\
& Summer & $20.6 \pm 5$ & $18.8 \pm 2.4$ & $20.4 \pm 4.5$ & $24.4 \pm 7.5$ & $21 \pm 3.1$ \\
\hline
\end{tabular}

S. D: Standard Deviation 
States Environmental Protection Agency (EPA). On this scale, pollution is categorized as being, respectively, at the lowest effect level (LEL), the heavily polluted category (HPC) and the severe effect level (SEL). The classifications in respect to the pollution levels found in this study are given in Table 4. Judging by the present results, El-Gamil beach can be considered a non-metal-polluted area, according to the OME and EPA classification criteria. These observations agree with those found by El-Sikaily et al. (2004) at other Egyptian coastal areas on the Mediterranean and Red Sea.

In the surface water samples collected during the present study, the concentrations of heavy metals were higher in the summer than in the winter (Table 5). As with the sediment samples, even though there was variability among sites, the overall concentration range for a particular metal was relatively narrow, with no values that appeared to be unusual. Not surprisingly, $\mathrm{Fe}$ concentrations were the highest, ranging from $822.6 \pm 14.7 \mu \mathrm{g} \mathrm{g}^{-1}$ at El Fardous, to $896 \pm 15 \mu \mathrm{g} \mathrm{g}^{-1}$ at El-Debba. Cd concentrations were the lowest and ranged from $0.8 \pm 1.3 \mu \mathrm{g} \mathrm{g}^{-1}$ at El-Gamil inlet to $2.7 \pm 0.11 \mu \mathrm{g} \mathrm{g}^{-1}$ at El-Fardous. Similar values were recorded by Kaiser et al. (2010), who stated that water contamination was found to be higher in the summer than in the winter along the Port Said coast on the Mediterranean.
The concentration of heavy metals $\left(\mu \mathrm{g} \mathrm{g}^{-1}\right.$ dry wt) in the soft tissue of $D$. trunculus is shown in Table 6. The concentrations of heavy metals in the bivalve samples were also higher in the summer than in the winter, and with the decreasing order of $\mathrm{Fe}>\mathrm{Zn}>\mathrm{Pb}>$ $\mathrm{Mn}>\mathrm{Cu}>\mathrm{Cd}$. Similar findings were given by Hornung and Oren (1981) and Abdallah and Abdallah (2008). Based on the data given in Table 6, it seems that the observed variation in metal levels in $D$. trunculus at different sites can be attributed to two mechanisms. The first is the availability of the metals in different sites, which in its turn depends on the pollution sources that of course vary across the sites. The second is that the animal utilizes different uptake and retention mechanisms which may also vary with physiological and environmental factors (Bryan, 1973) or even with the sexual state of the animal (Alexander and Young, 1976). Generally, however, the values of heavy metal concentration varied within an insignificant range in both seasons and across the sampling sites due to similar conditions affecting these sites. The highest concentration level of $\mathrm{Zn}$ $\left(36.4 \pm 3.8 \mu \mathrm{g} \mathrm{g}^{-1}\right)$ and $\mathrm{Cu}\left(4.8 \pm 0.3 \mu \mathrm{g} \mathrm{g}^{-1}\right)$ metals in the analyzed species are less than the maximum permissible levels (MPLs) of $100 \mu \mathrm{g} \mathrm{g}^{-1}$ and $10 \mu \mathrm{g} \mathrm{g}^{-1}$ for $\mathrm{Zn}$ and $\mathrm{Cu}$, respectively. The (MPLs) of $2 \mu \mathrm{g} \mathrm{g}^{-1}$, and $5 \mu \mathrm{g} \mathrm{g}^{-1}$ for $\mathrm{Cd}$ and $\mathrm{Pb}$ (declared by WHO, 1982; FAO, 1983; FAO/WHO, 1987; WHO, 2006), as well

Table 4. Classification of pollution level (total means) in $\mu \mathrm{g} / \mathrm{ml}$ of each element according to the American rules for sediment, in conformity to the lowest effect level, heavily polluted category and severe effect level, (modified from FreretMeurer et al., 2010)

\begin{tabular}{lcccc}
\hline Metals & Total Mean $(\mu \mathrm{g} / \mathrm{g})$ & LEL $(\mu \mathrm{g} / \mathrm{g})$ & HPC $(\mu \mathrm{g} / \mathrm{g})$ & SEL $(\mu \mathrm{g} / \mathrm{g})$ \\
\hline $\mathrm{Fe}(\mu \mathrm{g} / \mathrm{g})$ & 1895.15 & 20000 & 25000 & 40000 \\
$\mathrm{Mn}(\mu \mathrm{g} / \mathrm{g})$ & 211.98 & 460 & 500 & 1100 \\
$\mathrm{Cd}(\mu \mathrm{g} / \mathrm{g})$ & 1.94 & 0.6 & 6 & 10 \\
$\mathrm{Zn}(\mu \mathrm{g} / \mathrm{g})$ & 34.06 & - & - & - \\
$\mathrm{Cu}(\mu \mathrm{g} / \mathrm{g})$ & 6.83 & 16 & 50 & 110 \\
$\mathrm{~Pb}(\mu \mathrm{g} / \mathrm{g})$ & 21.52 & 31 & 60 & 250 \\
\hline
\end{tabular}

LEL: Lowest Effect Level; HPC: Heavily Polluted Category; SEL: Sever Effect Level

Table 5. Mean concentration of total heavy metals \pm standard deviation in water samples collected from El-Gamil Coast during winter 2005 and summer 2006

\begin{tabular}{|c|c|c|c|c|c|c|}
\hline \multirow[b]{2}{*}{ Metal } & \multirow[b]{2}{*}{ Season } & \multicolumn{4}{|c|}{ Sites } & \multirow[b]{2}{*}{$\begin{array}{c}\text { El-Debba Site } \\
\text { (5) }\end{array}$} \\
\hline & & $\begin{array}{l}\text { El-Gamil Airport } \\
\text { Site (1) }\end{array}$ & $\begin{array}{l}\text { El-Gamil Inlet Site } \\
\text { (2) }\end{array}$ & $\begin{array}{l}\text { El-Fardous Site } \\
\text { (3) }\end{array}$ & $\begin{array}{c}\text { El-Manasra Site } \\
\text { (4) }\end{array}$ & \\
\hline $\mathrm{Fe}$ & Winter & $786 \pm 14.4$ & $793.3 \pm 17$ & $744 \pm 19$ & $834.6 \pm 50$ & $841.3 \pm 14$ \\
\hline$(\mu \mathrm{g} / \mathrm{g})$ & Summer & $872.6 \pm 27$ & $832 \pm 24.9$ & $822.6 \pm 14.7$ & $846.6 \pm 30.2$ & $896 \pm 15$ \\
\hline $\mathrm{Mn}$ & Winter & $170 \pm 11.1$ & $174.6 \pm 7.5$ & $168.6 \pm 20.8$ & $162 \pm 15$ & $171.3 \pm 7.5$ \\
\hline$(\mu \mathrm{g} / \mathrm{g})$ & Summer & $198 \pm 5.2$ & $190.6 \pm 9$ & $180 \pm 7.2$ & $169.3 \pm 13$ & $187.3 \pm 6.4$ \\
\hline $\mathrm{Cd}$ & Winter & $2.4 \pm 0.3$ & $2.4 \pm 0.11$ & $2.7 \pm 1.5$ & $3.1 \pm 0.2$ & $2.8 \pm 4.2$ \\
\hline$(\mu \mathrm{g} / \mathrm{g})$ & Summer & $2.6 \pm 0.2$ & $0.8 \pm 1.3$ & $2.7 \pm 0.11$ & $2.6 \pm 0.2$ & $2.4 \pm 0.2$ \\
\hline $\mathrm{Zn}$ & Winter & $281.3 \pm 21.5$ & $287.3 \pm 16.7$ & $242.6 \pm 6.4$ & $277.3 \pm 16.2$ & $269.3 \pm 18.5$ \\
\hline$(\mu \mathrm{g} / \mathrm{g})$ & Summer & $300 \pm 17.4$ & $271.3 \pm 17.2$ & $283.3 \pm 16.2$ & $294.6 \pm 32.5$ & $282.6 \pm 20$ \\
\hline $\mathrm{Cu}$ & Winter & $15.3 \pm 2.3$ & $14 \pm 2$ & $16 \pm 2$ & $21.3 \pm 1.1$ & $17.3 \pm 4.1$ \\
\hline$(\mu \mathrm{g} / \mathrm{g})$ & Summer & $13.3 \pm 3$ & $12.6 \pm 2.3$ & $14 \pm 2$ & $19.3 \pm 1.1$ & $18.6 \pm 1.1$ \\
\hline $\mathrm{Pb}$ & Winter & $34.6 \pm 7$ & $31.3 \pm 5$ & $35.3 \pm 6.1$ & $44 \pm 2$ & $50 \pm 2$ \\
\hline$(\mu \mathrm{g} / \mathrm{g})$ & Summer & $42.6 \pm 8$ & $40 \pm 6$ & $41.3 \pm 6.4$ & $50.6 \pm 4.1$ & $56 \pm 7.2$ \\
\hline
\end{tabular}


Table.6 Mean concentration of total heavy metals \pm standard deviation in soft tissues of $D$. trunculus collected from ElGamil Coast during winter 2005 and summer 2006

\begin{tabular}{|c|c|c|c|c|c|c|}
\hline \multirow[b]{2}{*}{ Metal } & \multirow[b]{2}{*}{ Season } & \multicolumn{4}{|c|}{ Sites } & \multirow[b]{2}{*}{$\begin{array}{l}\text { El-Debba } \\
\text { Site (5) } \\
\text { Mean } \pm \text { S.D }\end{array}$} \\
\hline & & $\begin{array}{c}\text { El-Gamil Airport } \\
\text { Site (1) } \\
\text { Mean } \pm \text { S.D } \\
\end{array}$ & $\begin{array}{c}\text { El-Gamil Inlet } \\
\text { Site (2) } \\
\text { Mean } \pm \text { S.D }\end{array}$ & $\begin{array}{c}\text { El-Fardous } \\
\text { Site (3) } \\
\text { Mean } \pm \text { S.D }\end{array}$ & $\begin{array}{c}\text { El-Manasra } \\
\text { Site (4) } \\
\text { Mean } \pm \text { S.D } \\
\end{array}$ & \\
\hline \multirow[t]{2}{*}{$\mathrm{Fe}(\mu \mathrm{g} / \mathrm{g})$} & Winter & $52.8 \pm 0.5$ & $53.1 \pm 1.3$ & $57.2 \pm 3.6$ & $55.2 \pm 2$ & $47.2 \pm 2.5$ \\
\hline & Summer & $66.4 \pm 1.7$ & $61.8 \pm 0.9$ & $57.2 \pm 4.1$ & $60.7 \pm 3.3$ & $59.3 \pm 4.2$ \\
\hline \multirow[t]{2}{*}{$\mathrm{Mn}(\mu \mathrm{g} / \mathrm{g})$} & Winter & $4.8 \pm 0.3$ & $6.8 \pm 0.3$ & $6.4 \pm 0.1$ & $8.4 \pm 1.2$ & $7.9 \pm 0.6$ \\
\hline & Summer & $7.6 \pm 0.4$ & $6.8 \pm 0.4$ & $6 \pm 0.5$ & $7.1 \pm 1.2$ & $6.3 \pm 1.4$ \\
\hline \multirow[t]{2}{*}{$\mathrm{Cd}(\mu \mathrm{g} / \mathrm{g})$} & Winter & $2 \pm 0.1$ & $2.1 \pm 0.15$ & $1.6 \pm 0.3$ & $2.4 \pm 0.3$ & $2 \pm 0.3$ \\
\hline & Summer & $2 \pm 0.3$ & $2.2 \pm 0.2$ & $2.4 \pm 0.3$ & $2.1 \pm 0.1$ & $2.1 \pm 0.1$ \\
\hline \multirow[t]{2}{*}{$\mathrm{Zn}(\mu \mathrm{g} / \mathrm{g})$} & Winter & $34.4 \pm 0.7$ & $27.1 \pm 5.2$ & $25.2 \pm 1.5$ & $22 \pm 1.9$ & $26.8 \pm 3.2$ \\
\hline & Summer & $36.4 \pm 3.8$ & $34.8 \pm 0.8$ & $32.8 \pm 0.7$ & $33.4 \pm 0.5$ & $32.9 \pm 0.1$ \\
\hline \multirow[t]{2}{*}{$\mathrm{Cu}(\mu \mathrm{g} / \mathrm{g})$} & Winter & $3.6 \pm 0.2$ & $3.8 \pm 0.3$ & $4.8 \pm 0.3$ & $3.6 \pm 0.2$ & $3.2 \pm 0.2$ \\
\hline & Summer & $4.4 \pm 0.6$ & $4.2 \pm 0.5$ & $4 \pm 0.1$ & $4.3 \pm 0.1$ & $4.1 \pm 0.1$ \\
\hline \multirow[t]{2}{*}{$\mathrm{Pb}(\mu \mathrm{g} / \mathrm{g})$} & Winter & $6.8 \pm 1.7$ & $6.6 \pm 0.6$ & $5.6 \pm 0.9$ & $6.8 \pm 1.7$ & $7.2 \pm 0.1$ \\
\hline & Summer & $9.2 \pm 0.2$ & $9 \pm 0.3$ & $8.8 \pm 0.3$ & $9 \pm 0.2$ & $8.9 \pm 0.1$ \\
\hline
\end{tabular}

as maximum levels of $\mathrm{Cd}$ and $\mathrm{Pb}$ of 1.0 and $1.5 \mu \mathrm{g} \mathrm{g}^{-}$ 1 , respectively declared for bivalve mollusks by Commission Regulation (EC) (EU 2006) are, however, much lower than those detected in the soft tissues of $D$. trunculus with maximum values of $2.4 \pm 0.3 \mu \mathrm{g} \mathrm{g}^{-1}$ for $\mathrm{Cd}$ and $9.2 \pm 0.2 \mu \mathrm{g} \mathrm{g}^{-1}$ for $\mathrm{Pb}$. $D$. trunculus inhabiting El-Gamil beach along the western coast of Port Said on the Mediterranean Sea, therefore, is, in this respect, likely to be toxic for public health. Judging by the results of the present study the examined bivalve species (D. trunculus), was associated with enhanced metal content in its soft tissues and was unsafe within the limits for human consumption.

The concentration factor of metals or also considered to be an indicator of heavy metal accumulation in the tissues of aquatic organisms when expressed in relation to their concentration in the ambient water (Sultana and Rao, 1998). The concentration factor values for the studied metals in $D$. trunculus are delineated in Table 7. For $D$. trunculus, $\mathrm{Cd}$ gave the highest accumulation rate in the animal tissue with $\mathrm{C}_{f}$ values ranging between 833.33 and 592.59 in winter and 2750 and 769.23 in summer. The order of $\mathrm{C}_{f}$ in the soft tissues of $D$. trunculus was $\mathrm{Cd}>\mathrm{Cu}>\mathrm{Pb}>\mathrm{Zn}>\mathrm{Fe}>\mathrm{Mn}$, respectively. Thus, these patterns of magnitude were changed when the order carried out according to the level of heavy metals concentration in the soft tissues of the bivalve species, which were $\mathrm{Fe}>\mathrm{Zn}>\mathrm{Pb}>\mathrm{Mn}>\mathrm{Cu}>\mathrm{Cd}$. Thus, $\mathrm{Cd}$ and $\mathrm{Cu}$ moved from the end of the concentration pattern and occupied the top of the accumulation pattern $\left(\mathrm{C}_{f}\right)$. This phenomenon indicates that the studied species $D$. trunculus has a bioavailability to accumulate $\mathrm{Cd}$ and $\mathrm{Cu}$ from the surrounding medium greater than other metals and can suggest using of $D$. trunculus as a good indicator for the presence of highly toxic metals such as $\mathrm{Cd}$ and as a bio-indicator for essential metals such as $\mathrm{Cu}$. Increased $\mathrm{Cd}$ levels in the bivalve are worrying, especially considering the fact that it could be one of the most toxic heavy metals, even at relatively low concentrations (Fianko et al., 2007).

Statistically, significance analysis ( $\mathrm{P}$ values from the ANOVA-test) was performed between sites 1, 2, 3,4 , and 5. Although, there were differences in heavy metals concentrations between the different five sites, these differences in heavy metal concentration were not statistically significant $(\mathrm{P}>0.05)$. Thus there is no heavy metal adding source in any of the five sites chosen for the present study.

Various degrees of correlations were found between the elements, sand, silt, organic matter and calcium carbonate (Table 8) (Figures 2, 3, 4, 5). The correlation coefficient matrix between heavy metal concentrations and the physico-chemical characteristics of the sediment samples of El-Gamil beach showed some significant correlations, both positive and negative. There were positive relationships $(\mathrm{P}<0.05)$ between the six elements; $\mathrm{O} \mathrm{M}$ and $\mathrm{Mn} ; \mathrm{O} \mathrm{M}$ and $\mathrm{Zn} ; \mathrm{O} \mathrm{M}$ and $\mathrm{Cu} ; \mathrm{O} \mathrm{M}$ and $\mathrm{Pb}$; $\mathrm{CaCO}_{3}$ and $\mathrm{Cd}$; sand and $\mathrm{Fe}$; sand and $\mathrm{Mn}$; sand and $\mathrm{Cd}$; sand and $\mathrm{Cu}$; sand and $\mathrm{Pb}$; silt and $\mathrm{O} \mathrm{M}$. Moreover, an inverse significant correlations were noticed between $\mathrm{O} \mathrm{M}$ and $\mathrm{Fe} ; \mathrm{O} \mathrm{M}$ and $\mathrm{Cd} ; \mathrm{CaCO}_{3}$ and $\mathrm{Fe} ; \mathrm{CaCO}_{3}$ and $\mathrm{Mn} ; \mathrm{CaCO}_{3}$ and $\mathrm{Zn} ; \mathrm{CaCO}_{3}$ and $\mathrm{Cu} ; \mathrm{CaCO}_{3}$ and $\mathrm{Pb} ; \mathrm{CaCO}_{3}$ and $\mathrm{O} \mathrm{M}$.; sand and $\mathrm{O} \mathrm{M}$; silt and $\mathrm{Fe}$, silt and $\mathrm{Mn}$; silt and $\mathrm{Cd}$; silt and $\mathrm{Cu}$; silt and $\mathrm{Pb}$; silt and sand, and finally no significant correlations were found $(\mathrm{P}>0.05)$ between sand and $\mathrm{Zn}$; silt and $\mathrm{CaCO}_{3}$. These results can show that the six elements measured in the present study have similar sources and having similar sources can be related to geographical structure of this area.

\section{Conclusion}

This study was carried out to provide information on heavy metal concentrations in water, sediments and edible bivalve $D$. trunculus from the 
Table 7. Concentration factor of metals in the soft tissue of Donax trunculus during winter 2005 and summer 2006

\begin{tabular}{|c|c|c|c|c|c|c|c|}
\hline \multirow[b]{3}{*}{ Metal } & \multirow[b]{3}{*}{ Site } & \multicolumn{5}{|c|}{ Season } & \\
\hline & & \multicolumn{3}{|c|}{ Winter } & \multicolumn{3}{|c|}{ Summer } \\
\hline & & $\begin{array}{c}\text { Mean Concentration } \\
\text { of water }\end{array}$ & $\begin{array}{l}\text { Mean Concentration } \\
\text { of D. trunculus }\end{array}$ & $\mathrm{C}_{f}$ & $\begin{array}{c}\text { Mean concentration } \\
\text { of water }\end{array}$ & $\begin{array}{l}\text { Mean concentration } \\
\text { of } D . \text { trunculus }\end{array}$ & $\mathrm{C}_{f}$ \\
\hline \multirow[t]{5}{*}{$\mathrm{Fe}$} & $(1)$ & 786.0 & 52.8 & 67.17 & 872.6 & 66.4 & 76.09 \\
\hline & (2) & 793.3 & 53.1 & 66.93 & 832 & 61.8 & 74.27 \\
\hline & (3) & 744.0 & 57.2 & 76.88 & 822.6 & 57.2 & 69.53 \\
\hline & (4) & 834.6 & 55.2 & 66.13 & 846.6 & 60.7 & 71.69 \\
\hline & (5) & 841.3 & 47.2 & 56.10 & 896 & 59.3 & 66.18 \\
\hline \multirow[t]{5}{*}{$\mathrm{Mn}$} & (1) & 170 & 4.8 & 28.23 & 198 & 7.6 & 38.38 \\
\hline & (2) & 174.6 & 6.8 & 38.94 & 190.6 & 6.8 & 35.67 \\
\hline & (3) & 168.6 & 6.4 & 37.95 & 180 & 6.0 & 33.33 \\
\hline & (4) & 162.0 & 8.4 & 51.85 & 169.3 & 7.1 & 41.93 \\
\hline & (5) & 171.3 & 7.6 & 44.36 & 187.3 & 6.3 & 33.63 \\
\hline \multirow[t]{5}{*}{$\mathrm{Cd}$} & (1) & 2.4 & 2.0 & 833.33 & 2.6 & 2.0 & 769.23 \\
\hline & (2) & 2.4 & 2.0 & 833.33 & 0.8 & 2.2 & 2750 \\
\hline & (3) & 2.7 & 1.6 & 592.59 & 2.7 & 2.4 & 888.88 \\
\hline & (4) & 3.1 & 2.4 & 774.19 & 2.6 & 2.1 & 807.69 \\
\hline & (5) & 2.8 & 2.0 & 714.28 & 2.4 & 2.0 & 833.33 \\
\hline \multirow[t]{5}{*}{$\mathrm{Zn}$} & (1) & 281.3 & 34.4 & 122.28 & 300 & 36.4 & 121.33 \\
\hline & (2) & 287.3 & 27.1 & 94.32 & 271.3 & 34.8 & 128.27 \\
\hline & (3) & 242.6 & 25.2 & 103.87 & 283.3 & 32.8 & 115.77 \\
\hline & (4) & 277.3 & 22.0 & 79.33 & 294.6 & 33.4 & 113.37 \\
\hline & (5) & 269.3 & 26.8 & 99.51 & 282.6 & 32.9 & 116.41 \\
\hline \multirow[t]{5}{*}{$\mathrm{Cu}$} & (1) & 15.3 & 3.6 & 235.29 & 13.3 & 4.4 & 330.82 \\
\hline & (2) & 14.0 & 3.8 & 271.42 & 12.6 & 4.2 & 333.33 \\
\hline & (3) & 16.0 & 4.8 & 300.00 & 14 & 4.0 & 285.71 \\
\hline & (4) & 21.3 & 3.6 & 169.01 & 19.3 & 4.3 & 222.79 \\
\hline & (5) & 17.3 & 3.2 & 184.97 & 18.6 & 4.1 & 220.43 \\
\hline \multirow[t]{5}{*}{$\mathrm{Pb}$} & (1) & 34.6 & 6.8 & 196.53 & 42.6 & 9.2 & 215.96 \\
\hline & (2) & 31.3 & 6.6 & 210.86 & 40 & 9.0 & 225 \\
\hline & (3) & 35.3 & 5.6 & 158.64 & 41.3 & 9.0 & 2179 \\
\hline & (4) & 44.0 & 6.8 & 154.54 & 50.6 & 8.9 & 175.88 \\
\hline & (5) & 50.0 & 7.2 & 144.00 & 56.0 & 8.9 & 158.29 \\
\hline
\end{tabular}

Table 8. Correlation coefficient matrix between heavy metals, organic matter, calcium carbonate and sand grains size in sediment samples during summer 2006

\begin{tabular}{lllllllllll}
\hline & $\mathrm{Fe}$ & $\mathrm{Mn}$ & $\mathrm{Cd}$ & $\mathrm{Zn}$ & $\mathrm{Cu}$ & $\mathrm{Pb}$ & $\mathrm{O} . \mathrm{M} \%$ & $\mathrm{CaCO}_{3} \%$ & Sand \% & Silt \% \\
\hline $\mathrm{Fe}$ & 1 & & & & & & & & & \\
$\mathrm{Mn}$ & 0.847 & 1 & & & & & & & \\
$\mathrm{Cd}$ & 0.288 & 0.309 & 1 & & & & & & \\
$\mathrm{Zn}$ & 0.782 & 0.981 & 0.219 & 1 & & & & & \\
$\mathrm{Cu}$ & 0.438 & 0.749 & 0.735 & 0.724 & 1 & & & & \\
$\mathrm{~Pb}$ & 0.427 & 0.714 & 0.788 & 0.684 & 0.996 & 1 & & & \\
$\mathrm{O} . \mathrm{M} . \%$ & -0.317 & 0.11 & -0.479 & 0.166 & 0.091 & 0.091 & 1 & & \\
$\mathrm{CaCO} \%$ & -0.174 & -0.373 & 0.138 & -0.285 & -0.235 & -0.176 & -0.694 & 1 & & \\
$\mathrm{Sand} \%$ & 0.238 & 0.157 & 0.955 & 0.024 & 0.562 & 0.62 & -0.528 & 0.052 & 1 \\
$\mathrm{Silt} \%$ & -0.341 & -0.193 & -0.904 & -0.04 & -0.499 & -0.554 & 0.559 & 0.021 & -0.983 & 1 \\
\hline
\end{tabular}

O. M: Organic Matter; $\mathrm{CaCO} 3$ : Calcium Carbonate

Egyptian coasts of eastern Nile delta on the Mediterranean. Natural gas companies, pipeline industries and an electric power generating station are the main anthropogenic sources of heavy metals contamination in this region. Some results were above the limits for mollusks proposed by FAO/WHO, 1987 and EU, 2006. The present study has revealed that the concentrations of $\mathrm{Cd}$ and $\mathrm{Pb}$ in the soft tissues of the edible bivalve $D$. trunculus were above the maximum acceptable concentrations for human consumption. According to our results, the examined bivalve species D. trunculus was associated with enhanced metal content in its soft tissues and was unsafe within the limits for human consumption. Significantly positive correlations were reported between all elements; metals and sand, with strong positive 


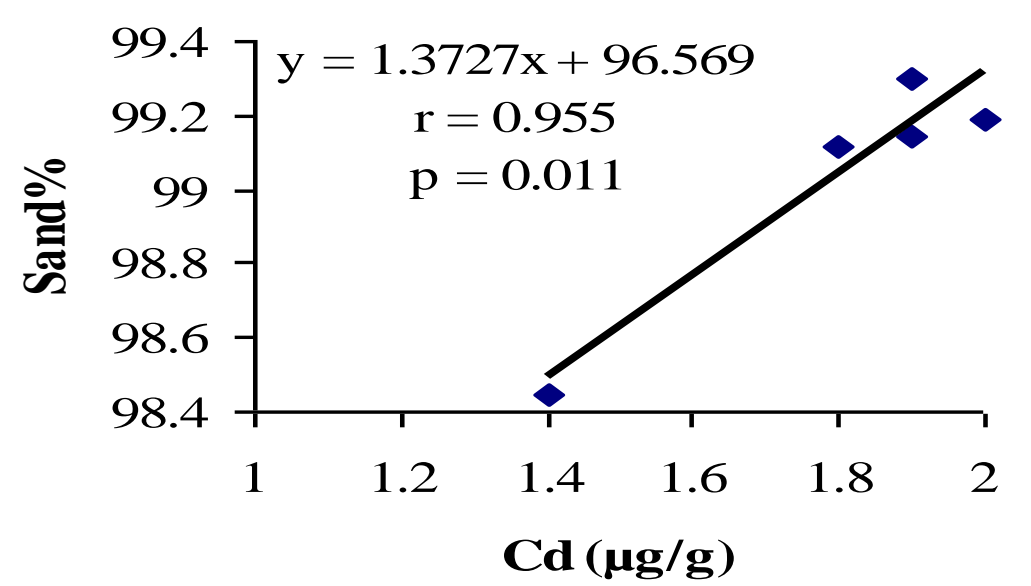

Figure 2. Correlation between $\mathrm{Cd}$ and sand in the bottom sediments of the El-Gamil Coast.

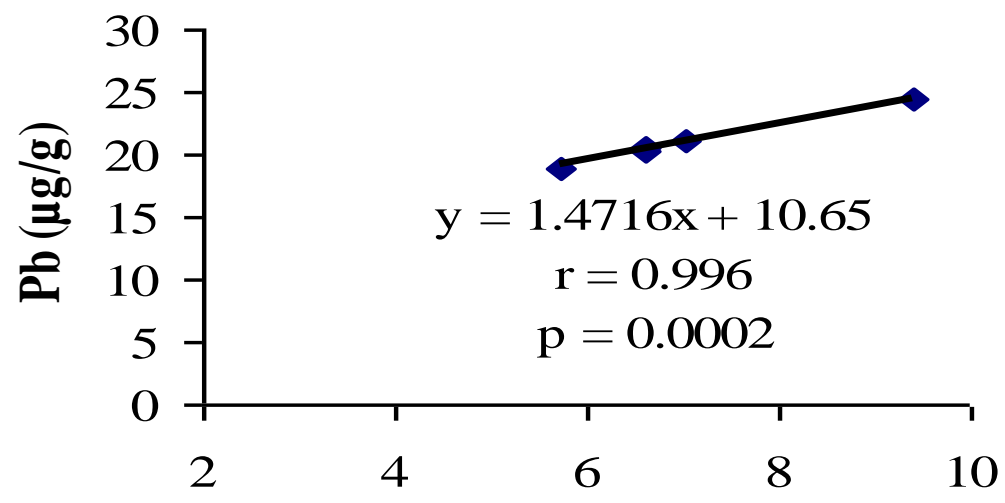

$\mathrm{Cu}(\boldsymbol{\mu g} / \mathrm{g})$

Figure 3. Correlation between $\mathrm{Cu}$ and $\mathrm{Pb}$ in the bottom sediments of the El-Gamil Coast.

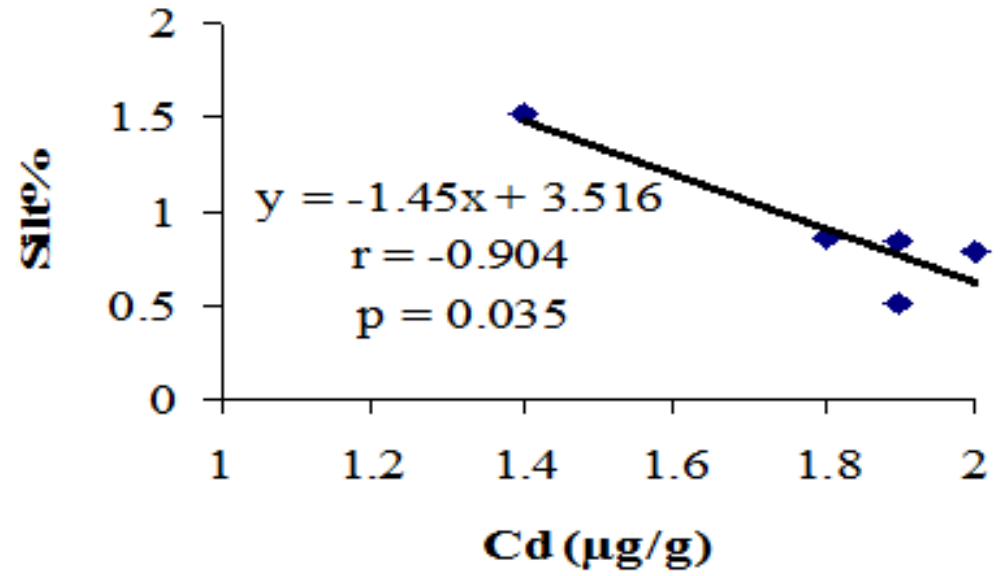

Figure 4. Correlation between $\mathrm{Cd}$ and silt in the bottom sediments of the El-Gamil Coast.

correlations between $\mathrm{Cu}$ and $\mathrm{Pb}$ and $\mathrm{Cd}$ and sand while there were, strong inverse correlations between $\mathrm{Cd}$ and silt, and sand and silt. Although, levels of heavy metals in water and sediment are not high, a potential danger may emerge in the future depending on the domestic waste waters and agricultural activities in this region. Mean metal concentrations were found to be higher in some sites than others, but, these differences in concentrations were not statistically significant $(\mathrm{P}>0.5)$, suggesting that sources contributing to the pollution of any of the five sites chosen along El-Gamil coast on the Mediterranean sea are not much different from that of the other. We conclude that, the area of the present 


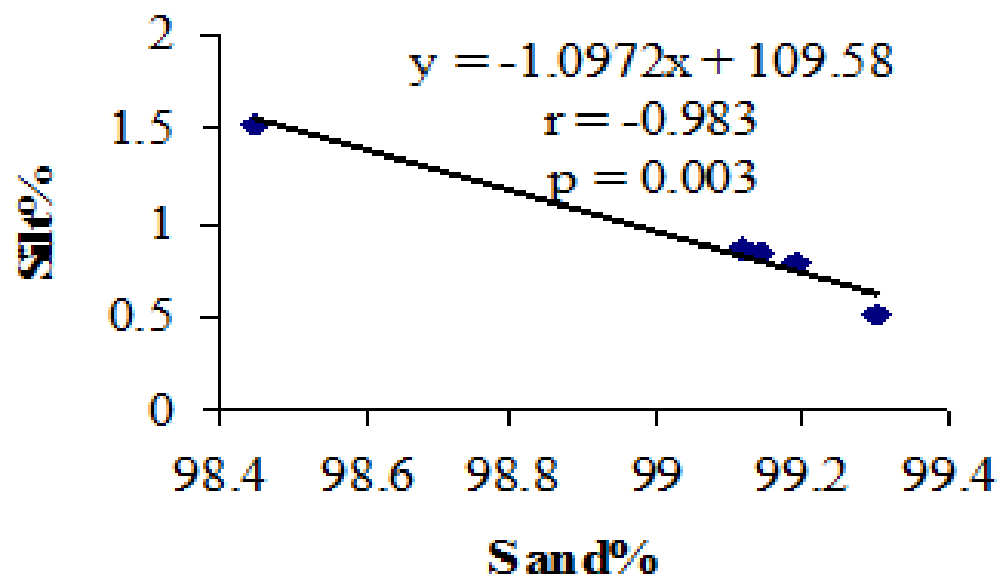

Figure 5. Correlation between sand and silt in the bottom sediments of the El-Gamil Coast.

study is in general not considered a metal polluted area according to the OME and EPA classification criteria. However, concentrations of $\mathrm{Cd}$ and especially, $\mathrm{Pb}$ did give some cause for concern, and warrants a continued monitoring programme for inorganic and chemical organic compounds in sediments, water, and biota along the Egyptian Mediterranean coasts. Such a programme will assist the development of an effective coastal management programme to protect the ecological integrity of this valuable ecosystem and the health of humans associated with it.

\section{Acknowledgements}

The authors would like to acknowledge the support of King Saud University, Distinguished Scientist Fellowship Program, Riyadh 11451, Saudi Arabia.

\section{References}

Abdallah, M.A.M. and Abdallah, A.M.A. 2008. Biomonitoring study of heavy metals in biota and sediments in the South Eastern Coast of Mediterranean Sea, Egypt. Environmental Monitoring and Assessment, 146: 139-145.

Alexander, G. and Young, D. 1976. Trace metals in Southern California mussels. Marine Pollution Bulletin, 7: 7-9.

APHA, 1992. Standard Methods for the examination of waters and wastewaters. $16^{\text {th }}$ ed., (Washington, DC; American Public Health Association).

Argese, E., Ramieri, E., Bettiol, C., Pavoni, B., Chiozzotto, E. and Sfriso, A. 1997. Pollutant exchange at the water/sediment interface in the Venice canals. Water, Air, and Soil Pollution, 99: 255-263

Brar, N.K., Waggoner, C., Reyes, J.A., Fairy, R. and Kelley, K.M. 2009. Evidence for thyroid endocrine disruption in wild fish in San Francisco Bay, California, USA. Relationships to contaminant exposures. Aquatic Toxicology doi: 10.1016/j.aquatox.2009.10.023.

Bryan, G. 1973. The occurrence and seasonal variation of trace metals in scallops Pecten maximus and Chlayms opercularis. Journal of Marine Biological Association, 53: 145-166.

Cardoso, A.G.A., Boaventura, G.R., Filho, E.V.S. and Brod, J.A. 2001. Metal distribution in sediments from the Ribeira Bay, Rio de Janeiro, Brazil. Brazilian Chemical Society, 12 (6): 767-774.

Collier, T.K., Johnson, L.L., Stehr, C.M., Myers, M.S. and Stein, J.E. 1998. A comprehensive assessment of the impacts of contaminants on fish from an urban waterway. Marine Environmental Research, 46: 243247.

Daskalakis, K.D. and O'Connor, T.P. 1995. Normalization and elemental sediment contamination in the coasts of United States. Environmental Science and Technology, 29: 470-477.

Díez, S., Delgado, S., Aguilera, I., Astray, J., Pérez-Gómez, B., Torrent, M., Sunyer, J. and Bayona, J.M. 2009. Prenatal and early childhood exposure to mercury and methyl mercury in Spain, a high-fish-consumer country. Archives of Environmental Contamination and Toxicology, 56: 615-622.

Dowidar, M. 1988. Productivity of the southeastern Mediterranean. In natural and man-made hazard, ElSabh, M.I. and Murty, T.S., eds., 477-498.

El-Sikaily, A., Khaled, A. and El-Nemr, A. 2004. Heavy metals monitoring using bivalves from Mediterranean Sea and Red Sea. Environmental Monitoring and Assessment, 98 (1-3): 41-58.

Erdoğrul, Ö. and Erbilir, F. 2007. Heavy metal and trace elements in various fish samples from Sir Dam Lake, Kahramanmaraş, Turkey, Environmental Monitoring Assessment, 130: 373-379.

EU, 2006. Setting maximum levels for certain contaminants in foodstuffs. Commission Regulation (EC) No 1881/ 2006, Official journal of the European Union 364: 5 24.

El-Moselhy, K., El-Samra, M. and Abd-El-Azim, H. 2005. Concentration of nine heavy metals in Suez Canal waters, Egypt. Egyptian Journal of Aquatic Research, 31(2): 145-165.

FAO, 1983. Compilation of legal limits for hazardous substances in fish and fishery products, FAO Fishery Circular, $464 \mathrm{pp}$.

FAO/WHO, 1987. Principles of the safety assessment of food additives and contaminants in food environmental health criteria, Geneva, No: 70. 
Fianko, J.R., Osae, S., Adomako, D., Adotey, D.K. and Serrfor-Armah, Y. 2007. Assessment of heavy metal pollution of the Iture estuary in the central region of Ghana. Environmental Monitoring and Assessment, 131: 467-473.

Folk, R. 1974. Petrography of sedimentary rocks. Herrphill, Texas, $182 \mathrm{pp}$.

Fox, G.A., Collins, B., Hayakawa, E., Weseloh, D.V., Ludwig, J.P., Kubiak, T.J. and Erdman, T.C. 1991. Reproductive outcomes in colonial fish-eating birds: a biomarker for occurrence and prevalence of bill defects in young double-crested cormorants in the Great Lakes, 1979-1987. Journal of Great Lakes Research, 17: 158-167.

Freedman, B. 1989. The impact of pollution and other stresses on ecosystem structure and function. Academic Press, London.

Freret-Meurer, N.V., Andreata, J.V., Meurer, B.C., Manzano, F.V., Baptista, M.G.S., Teixeira, D.E. and Longo, M.M. 2010. Spatial distribution of metals in sediments of the Riberia Bay, Angra dos Reis, Rio de Janeriro, Brazil. Marine Pollution Bulletin, 60: 627629.

Friedman, G. and Johnson, K. 1982. Exercises in Sedimentology. John Wiley and Sons, Inc, USA, 366 pp.

Hamed, M. 1996. Determination of some micro-elements in aquatic ecosystems and their relation to the efficiency of aquatic life. PhD. Thesis, Mansoura University, Faculty of Science, Egypt.

Hornung, H. and Oren, O.H. 1981. Heavy metals in Donax trunculus L. in Haifa Bay, Mediterranean (Israel). Marine Environmental Research, 4(3): 195-201.

Huang, X., Hites, R.A., Foran, J.A., Hamilton, C., Knuth, B.A., Schwager, S.J. and Carpenter, D.O. 2006. Consumption advisories for salmon based on risk of cancer and noncancer health effects. Environmental Research, 101: 263-274.

Jefferies, D.J. and Firestone, P. 1984. Chemical analysis of some coarse fish from a Suffolk River carried out as part of the preparation for the first release of captivebred otters. Journal of Otter Trust, 1(18):17-22.

Kaiser, M.F., Aboulela, H., El-Serehy, H. and Ezz Edin, H. 2010. Spectral enhancement of SPOT imagery data to assess marine pollution near Port Said, Egypt. International Journal of Remote Sensing, 31 (7): 1753-1764.

Ketata, I., Smaoui-Damak, W., Guermazi, F., Rebai, T. and Hamza-Chaffai, A. 2007. In situ endocrine disrupting effects of cadmium on the reproduction of Ruditapes descussatus. Comparative Biochemistry and Physiology, 146 (5): 415-430.

Kumar Singh, R., Chavan, S.L. and Sapkale, P.H. 2007. Heavy metal concentrations in water, sediments and body tissues of red worm (Tubifex sp.) collected from natural habitats in Mumbai, India, Environmental Monitoring and Assessment, 129: 471-481.

Liu, J., Goyer, R.A. and Waalker, M.P. 2008.Toxic effects of metals. In: C.D. Klaasen (Ed.), Casarett and Doull's Toxicology. The Basic Science of Poisons. McGraw-Hill, New York: 931-979.

Long, E.R., Macdonald, D.D., Smith, S.L. and Calder, F.D. 1995. Incidence of adverse biological effects within ranges of chemical concentration in marine and estuarine sediments. Environmental Management, 19: 81-97.

Nirmala, K., Oshima, Y., Lee, R., Imada, N., Honjo, T. and Kobayashi, K. 1999. Transgenertaional toxicity of tributyltin and its combined effects with polychlorinated biphenyls on reproductive processes in Japanese Medaka (Oryzias latipes). Environmental Toxicology and Chemistry, 18: 717-721.

Oregioni, B. and Astone, S. 1984. The determination of selected trace metals in marine sediments by flameless/flame-atomic absorption spectrophotometry. IAEA Monaco Laboratory, Internal Report.

Renzoni, A., Zino, F. and Franchi, E. 1998. Mercury levels along the food chain and risk for exposed populations. Environmental Research, 77: 68-72.

Ross, P. and Delorenzo, M.E. 1997. Sediment contamination problems in the Caribbean islands: research and regulation. Environmental Toxicology and Chemistry, 16: 52-58.

Singh, B.R. and Steinnes, E. 1994. Soil and water contamination by heavy metals. In R. LAl and B. A. Stewart (Eds.) Soil processes and water quality. Lewis, Boca Raton, Florida. pp: 233-272.

Steel, R.G.D. and Torrie, J.H. 1986. Principles and procedures of statistics. A biometric approach. Second Edition. McGraw Hill, Inc.

Sultana, R. and Rao, D. 1998. Bioaccumulation patterns of Zinc, Copper, Lead and Cadmium in Grey Mullet, Mugil cephalus (L.) from harbour waters of Visakhapmum, India. Bulletin of the Environmental Contamination and Toxicology, 60: 949-955.

Tam, N. and Wong, Y., 2000. Spatial variation of heavy metals in surface sediment of Hong Kong mangrove swamps. Environmental Pollution, 110: 195-205.

Underwood, A.J. 1981. Techniques of analysis of variance in experimental biology and ecology. Oceanography and Marine Biology Annual Review, 19: 513-605.

UNEP/ FAO/ IAEA/ IOC 1984. Sampling of selected marine organisms and sample preparation for trace metal analysis. Reference methods for marine pollution studies. Review, 2: 19.

WHO, 1982. Toxicological evaluation of certain food additives, WHO Food Addit. Ser. No. 17, World Health Org., Geneva: 28-35.

WHO 2006. Joint FAO/WHO Expert Committee on Food Additives. Meeting (67 $7^{\text {th. }}$ 2006: Rome, Italy) Evaluation of certain food additives and contaminants: sixty-seventh report of the Joint FAO/WHO Expert Committee on Food Additives. (WHO technical report series; No. 940).

Yáñez- Arancibia, A. and Sánchez-Gil, P. 1988. Ecologia de los recursos demersales marions, first edicao. AGT Editor S/A Mexico, D, P. 189 pp. 